\title{
Corrosion Resistance of High-Mn Austenitic Steels for the Automotive Industry
}

\author{
Adam Grajcar \\ Silesian University of Technology \\ Poland
}

\section{Introduction}

Significant progress in a field of development of new groups of steel sheets for the automotive industry has been made in the period of the last twenty years. From the aspect of materials, this development has been accelerated by strong competition with non-ferrous aluminium and magnesium alloys as well as with composite polymers, which meaning has been successively increasing. From the aspect of ecology, an essential factor is to limit the amount of exhaust gas emitted into the environment. It is strictly connected to fuel consumption, mainly dependent on a car weight. Application of sheets with lower thickness preserving proper stiffness requires the application of sheets with higher mechanical properties, keeping adequate formability. Figure 1 presents conventional high-strength steels (HSS) and the new generations of advanced high-strength steels (AHSS) used in the automotive industry. Steels of IF (Interstitial Free) and BH (Bake Hardening) type with moderate strength and high susceptibility to deep drawing were elaborated for elements of body panelling. However, the increasing application belongs to new multiphase steels consisting of ferritic matrix containing martensitic islands (DP - Dual Phase) or bainiticaustenitic regions (TRIP - Transformation Induced Plasticity). These steels together with CP (Complex Phase) and MART steels with the highest strength level are the first generation of advanced high-strength steels (AHSS) used for different reinforcing elements (International Iron \& Steel Institute, 2006).

Nowadays, apart from limiting fuel consumption, special pressure is placed on increasing the safety of car users. The role of structural elements such as frontal frame members, bumpers and other parts is to take over the energy of an impact. Therefore, steels that are used for these parts should be characterized by high product of UTS and UEl, proving the ability of energy absorption. It is difficult to achieve for conventional HSS and the first generation AHSS because the ductility decreases with increasing strength (Fig. 1).

The requirements of the automotive industry can be met by the second generation of advanced high-strength steels combining exceptional strength and ductile properties as well as cold formability (Fig. 1). These TWIP (Twinning Induced Plasticity) and L-IP (Light Induced Plasticity) steels belong to a group of high-manganese austenitic alloys but are much cheaper comparing to Cr-Ni stainless steels (AUST SS). Their mean advantage over first generation steels with a matrix based on A2 lattice structure is the great susceptibility of austenite on plastic deformation, during which dislocation glide, mechanical twinning 
and/or strain-induced martensitic transformation can occur. The group of high-manganese steels includes alloys with $15-30 \% \mathrm{Mn}$ content. Two mean chemical composition strategies had been worked out so far. The first includes alloys with different Mn concentration and 0.5 to $0.8 \%$ C (Ghayad et al., 2006; Jimenez \& Frommeyer, 2010). The function of carbon is stabilization of $\gamma$ phase and hardening of solid solution. In the second group, the concentration of carbon is decreased below $0.1 \%$, whereby there is an addition up to $4 \% \mathrm{Al}$ and/or 4\% Si (Frommeyer et al., 2003; Graessel et al., 2000). The solid solution strengthening caused by $\mathrm{Al}$ and $\mathrm{Si}$ compensates smaller $\mathrm{C}$ content. Sometimes, the steels contain chromium (Hamada, 2007; Mujica Roncery et al., 2010) or microadditions of $\mathrm{Nb}$, Ti and B (Bleck \& Phiu-on, 2005; Grajcar et al., 2009; Huang et al., 2006).

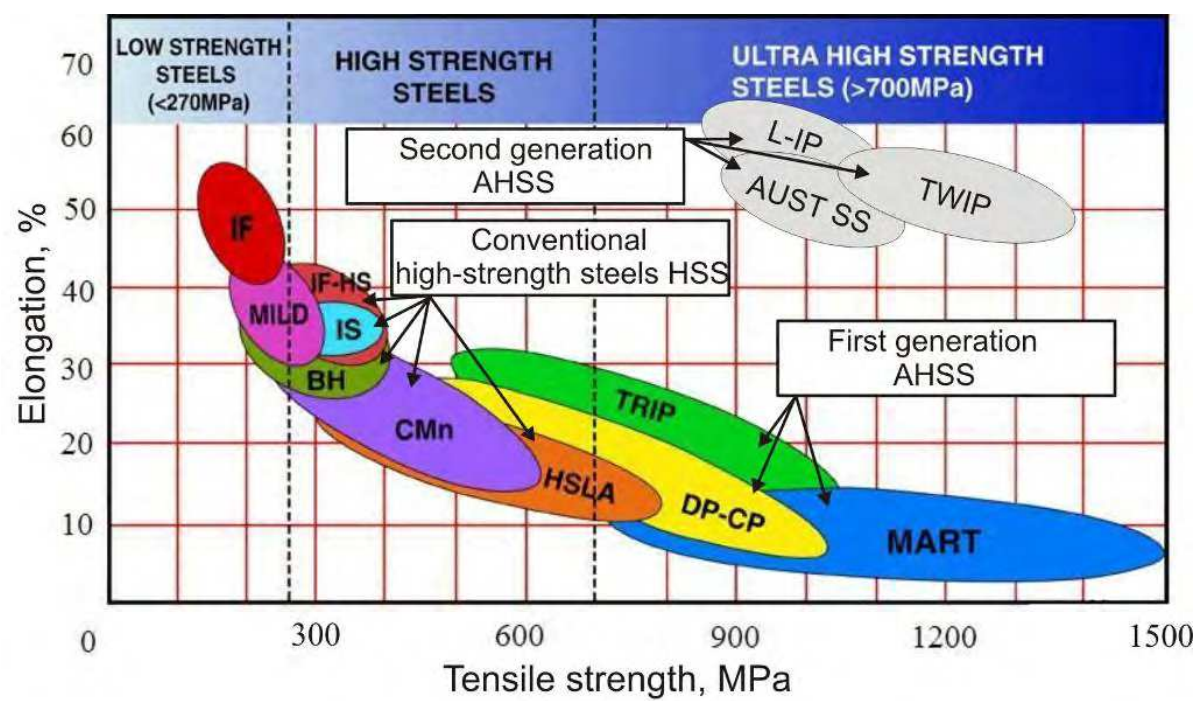

Fig. 1. Conventional high-strength steels (HSS) and the new generations of advanced highstrength steels (AHSS) used in the automotive industry (International Iron \& Steel Institute, 2006).

Mechanical properties of high-manganese steels are dependent on structural processes occurring during cold deformation, which are highly dependent on SFE (stacking fault energy) of austenite (De Cooman et al., 2011; Dumay et al., 2007; Vercammen et al., 2002). In turn, the SFE is dependent on the temperature and chemical composition. Figure 2 shows that the stacking fault energy increases with increasing temperature and $\mathrm{Al}, \mathrm{Cu}$ content whereas Cr and Si decrease it (Dumay et al., 2007; Hamada, 2007). If the SFE is from 12 to 20 $\mathrm{mJm}^{-2}$, a partial transformation of austenite into martensite occurs as a main deformation mechanism, taking advantage of TRIP effect.

Values of SFE from 20 to $60 \mathrm{mJm}^{-2}$ determine intensive mechanical twinning related to TWIP effect. At SFE values higher than about $60 \mathrm{mJm}^{-2}$, the partition of dislocations into Shockley partial dislocations is difficult, and therefore the glide of perfect dislocations is the dominant deformation mechanism (Hamada, 2007). In TRIPLEX steels with a structure of austenite, ferrite and $\kappa$-carbides $\left((\mathrm{Fe}, \mathrm{Mn})_{3} \mathrm{AlC}\right)$ and for SFE $>100 \mathrm{mJm}^{-2}$, the SIP (Shear Band Induced 
Plasticity) effect is considered as the major deformation mechanism (Frommeyer \& Bruex, 2006). High impact on the dominating deformation mechanism have also the temperature, strain rate and grain size (Dini et al., 2010; Frommeyer et al., 2003; Graessel et al., 2000). The key to obtain the mechanical properties regime in Fig. 1 is the high work hardening rate characterizing the plastic deformation of high-Mn alloys. The high level of ductility is a result of delaying necking during straining. In case of the local presence of necking, straininduced martensitic transformation occurs in such places (in TRIP steels) or deformation twins are preferably generated in locally deformed areas (in TWIP steels). It leads to intensive local strain hardening of the steel and further plastic strain proceeds in less strainhardened adjacent zones. The situation is repeated in many regions of the sample what finally leads to delaying necking in a macro scale and high uniform and total elongation. The shear band formation accompanied by dislocation glide occurs in deformed areas of TRIPLEX steels and the SIP effect is sustained by the uniform arrangement of nano size $\kappa$ carbides coherent to the austenitic matrix (Frommeyer \& Bruex, 2006).

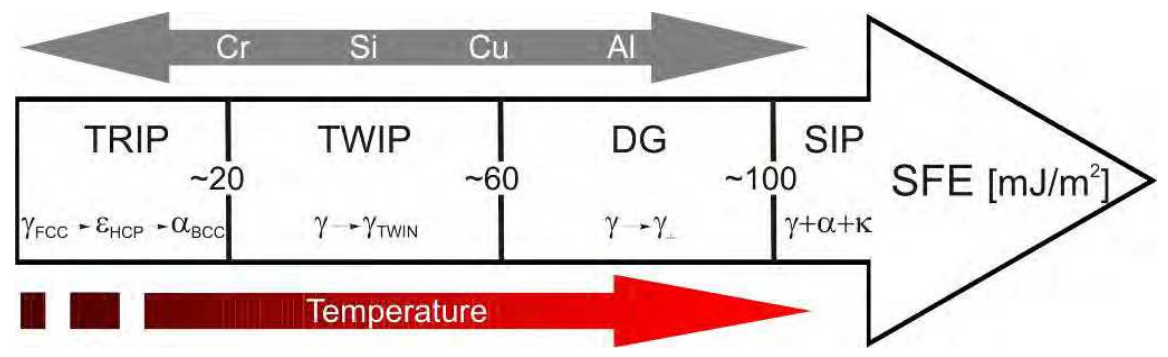

Fig. 2. Schematic drawing of the effects of temperature and chemical composition on the stacking fault energy (SFE) of austenite and the correlation of SFE with a main deformation mechanism in high-Mn alloys.

\section{Corrosion behaviour}

\subsection{General and pitting corrosion}

The mean area of studies on high-manganese steels concern their high-temperature deformation resistance (Bleck et al., 2007; Cabanas et al., 2006; Dobrzański et al., 2008; Grajcar \& Borek, 2008; Grajcar et al., 2009) and the cold-working behaviour (Dini et al., 2010; Frommeyer \& Bruex, 2006; Frommeyer et al., 2003; Graessel et al., 2000; Huang et al., 2006). Much less attention has been paid on their corrosion resistance (Ghayad et al., 2006; Grajcar et al., 2010a, 2010b; Hamada, 2007; Kannan et al., 2008; Mujica et al., 2010; Mujica Roncery et al., 2010; Opiela et al., 2009). The research on Fe-C-Mn-Al alloys (Altstetter et al., 1986) for cryogenic applications that were supposed to substitute expensive $\mathrm{Cr}-\mathrm{Ni}$ steels was carried out in the eighties of the last century. The role of manganese boils to Ni replacement and obtaining austenitic microstructure, whereas aluminium has a similar impact as chromium. Improvement of corrosion resistance by $\mathrm{Al}$ consists in formation of thin, stable layer of oxides. As the result of conducted research it was found that Fe-C-Mn-Al alloys show inferior corrosion resistance than $\mathrm{Cr}-\mathrm{Ni}$ steels and they can be used as a substitute only in some applications (Altstetter et al., 1986). The addition of $25 \% \mathrm{Mn}$ to mild steels was found to be very detrimental to the corrosion resistance in aqueous solutions (Zhang \& Zhu, 1999). 
The Fe-25Mn alloy was difficult to passivate, even in such neutral aqueous electrolytes as $1 \mathrm{M} \mathrm{Na}_{2} \mathrm{SO}_{4}$ solution. With increasing $\mathrm{Al}$ content up to $5 \%$ of the Fe-25Mn-Al steel, the anodic polarization curves exhibit a stable passivation region in $\mathrm{Na}_{2} \mathrm{SO}_{4}$ solution, but it shows no passivation in $3.5 \mathrm{wt} \% \mathrm{NaCl}$ solution.

Recently, corrosion resistance of Fe-0.05C-29Mn-3.1Al-1.4Si steel in acidic $\left(0.1 \mathrm{M} \mathrm{H}_{2} \mathrm{SO}_{4}\right)$ and chloride-containing ( $3.5 \mathrm{wt} \% \mathrm{NaCl}$ ) environments was investigated (Kannan et al., 2008). Moreover, the corrosion behaviour of the tested high-Mn steel with that of IF-type was compared. Performing immersion and polarization tests it was found that Fe-Mn-Al-Si steel has lower corrosion resistance than IF steel, both in acidic and in chloride media. The corrosion resistance of the high-manganese steel in chloride solutions is higher compared to that observed in acidic medium. The behaviour of Fe-0.2C-25Mn-(1-8)Al steels with increased concentration of $\mathrm{Al}$ up to $8 \% \mathrm{wt}$. in $3.5 \mathrm{wt} \% \mathrm{NaCl}$ was also investigated (Hamada, 2007). Hamada reported that the corrosion resistance of tested steels in chloride environments is pretty low. The predominating corrosion type is the general corrosion, but locally corrosion pits were observed. In steels including up to $6 \% \mathrm{Al}$ with homogeneous austenite structure, places where the pits occur are casually, whereas in case of two-phase structure, including ferrite and austenite (Fe-0.2C-25Mn-8Al), they preferentially occur in $\alpha$ phase. The corrosion resistance of examined steels can be increased trough anodic passivation in nitric acid, which provides modification of chemical composition and constitution of the surface layer (Hamada et al., 2005). This was done by reducing the surface concentration of $\mathrm{Mn}$ and enriching the surface layer in elements that improve the corrosion resistance (e.g. $\mathrm{Al}, \mathrm{Cr}$ ).

A better effect was reached by chemical composition modification. It was found that addition of $\mathrm{Al}$ and $\mathrm{Cr}$ to $\mathrm{Fe}-0.26 \mathrm{C}-30 \mathrm{Mn}-4 \mathrm{Al}-4 \mathrm{Cr}$ and $\mathrm{Fe}-0.25 \mathrm{C}-30 \mathrm{Mn}-8 \mathrm{Al}-6 \mathrm{Cr}$ alloys increases considerably the general corrosion resistance, especially after anodic passivation ageing of surface layers in an oxidizing electrolytic solution (Hamada, 2007). Cr-bearing steels passivated by nucleation and growth of the passive oxide films on the steel surface, where the enrichment of $\mathrm{Al}$ and $\mathrm{Cr}$ and depletion of Fe and $\mathrm{Mn}$ have occurred. The positive role of $\mathrm{Cr}$ in obtaining passivation layers in $0.5 \mathrm{M} \mathrm{H}_{2} \mathrm{SO}_{4}$ acidic solution was recently confirmed in Fe-25Mn-12Cr-0.3C-0.4N alloy (Mujica et al., 2010; Mujica Roncery et al., 2010). The steel containing increased $\mathrm{Cr}, \mathrm{C}$ and $\mathrm{N}$ content shows passivity at the current density being five orders of magnitude lower compared to the Fe-22Mn-0.6C steel.

\subsection{Effect of deformation}

Results of corrosion tests described above concern steels in the annealed or supersaturated state. The influence of cold plastic deformation on corrosion behaviour in $3.5 \mathrm{wt} \% \mathrm{NaCl}$ was studied in Fe-0.5C-29Mn-3.5Al-0.5Si steel (Ghayad et al., 2006). It was found on the basis of potentiodynamic tests, that the steel shows no tendency to passivation, independently on the steel structure after heat treatment (supersaturated, aged or strain-aged). Higher corrosion rate of deformed specimens than that of specimens in supersaturated state, was a result of faster steel dissolution caused by annealing twins, which show a different potential than the matrix. The highest corrosion rate was observed in strain-aged samples, as a result of ferrite formation, which creates a corrosive galvanic cell with the austenitic matrix. The enhanced corrosion attack at the boundaries of deformation twins was also observed in Fe22Mn-0.5C steels (Mazancova et al., 2010). 


\subsection{Hydrogen embrittlement and delayed fracture}

Generally, increasing the strength of steels, their hydrogen embrittlement susceptibility increases. This is one of the main problem to use AHSS. If hydrogen content reaches the critical value, it can induce a reduction of strength and ductile properties. A critical concentration of hydrogen is various for different steels (Lovicu et al., 2010; Sojka et al., 2010). Hydrogen embrittlement is usually investigated by performing slow strain rate tensile tests on hydrogenerated samples. Austenitic alloys are considered to be immune to this type of corrosion damage. However, the stress- or strain-induced martensitic transformation of austenite taking place in TRIP-aided austenitic alloys can be a reason of their embrittlement. This can happen due to the high difference in solubility and diffusion rate of hydrogen in the BCC and FCC lattice. Austenite is characterized by high solubility and low diffusivity of $\mathrm{H}$ in the $\mathrm{A} 1$ lattice and thus acts as a sink for hydrogen lowering its mobility and increasing the hydrogen concentration. Due to the slow diffusion rate of hydrogen in austenite, it is hardly to enrich it homogeneously to a hydrogen content causing embrittlement. However, it was shown (Lovicu et al., 2010) that the hydrogen concentration in surface regions of the high-Mn steel is much higher than in the centre zone. It can lead to the intragranular fracture in these regions because of strain-induced or hydrogen-induced martensitic transformation and finally to reduction of strength and ductility.

When the formed automotive element is exposed to the air the delayed fracture can occur. The technological formability is usually investigated in cup forming tests (Otto et al., 2010; Shin et al., 2010). It was observed (Shin et al., 2010) that the 0.6C-22Mn steel cup specimen underwent the delayed fracture when exposed to the air for seven days, even though the specimen was not cracked during forming. This is because the strain-induced martensitic transformation occurred during the cupping test in places of stress concentration. When the addition of $1.2 \% \mathrm{Al}$ was added the steel cup forms with the high share of mechanical twinning instead the $\gamma \rightarrow \alpha^{\prime}$ transformation. It leads to lower stress concentration and finally to improvement in cup formability (Shin et al., 2010).

\section{Experimental procedure}

\subsection{Material}

The chapter addresses the corrosion behaviour of two high-Mn steels of different initial structures in chloride and acidic media. Their chemical composition is given in Table 1.

\begin{tabular}{|c|c|c|c|c|c|c|c|c|c|c|c|}
\hline Steel grade & $\mathrm{C}$ & $\mathrm{Mn}$ & $\mathrm{Si}$ & $\mathrm{Al}$ & $\mathrm{Nb}$ & $\mathrm{Ti}$ & $\mathrm{S}$ & $\mathrm{P}$ & $\mathrm{N}$ & $\mathrm{O}$ & Structure \\
\hline 26Mn-3Si-3Al-Nb & 0.065 & 26.0 & 3.08 & 2.87 & 0.034 & 0.009 & 0.013 & 0.004 & 0.0028 & 0.0006 & $\gamma$ \\
\hline 25Mn-3Si-1.5Al-Nb-Ti & 0.054 & 24.4 & 3.49 & 1.64 & 0.029 & 0.075 & 0.016 & 0.004 & 0.0039 & 0.0006 & $\gamma+\varepsilon$ \\
\hline
\end{tabular}

Table 1. Chemical composition of the investigated steels, wt. \%

The vacuum melted steels have similar C, Mn and Si concentration. Significant impact on the SFE of austenite has the difference in $\mathrm{Al}$ and Ti content. The lower SFE of 25Mn-3Si$1.5 \mathrm{Al}-\mathrm{Nb}$-Ti steel compared to $26 \mathrm{Mn}-3 \mathrm{Si}-3 \mathrm{Al}-\mathrm{Nb}$ steel is a result of the lower $\mathrm{Al}$ content. Moreover, several times higher Ti content in a first steel provides a decrease of $\gamma$ phase stability, as a result of fixing the total nitrogen and some carbon (Grajcar et al., 2009). 
The steels were delivered in a form of sheet segments of 340x225x3.2 mm, obtained after the thermo-mechanical rolling. The thermo-mechanical processing consisted of:

- heating the charge up to the temperature of $1100^{\circ} \mathrm{C}$ and austenitizing for 15 minutes,

- rolling in a range from $1050^{\circ} \mathrm{C}$ to $850^{\circ} \mathrm{C}$ in 3 passes (relative reduction: 20,15 and $15 \%)$,

- holding of the rolled sheet segments at the temperature of finishing rolling for $15 \mathrm{~s}$,

- $\quad$ solution heat treatment of the flat specimens in water.

The microstructures of the steels after the thermo-mechanical treatment are shown in Figs. 3 and 4 . The 26Mn-3Si-3Al-Nb steel exhibits a homogeneous austenite structure with grains elongated in the rolling direction (Fig. 3a). The susceptibility to twinning confirms the presence of a great number of annealing twins. The single-phase structure of the steel is confirmed by X-ray diffraction pattern in Fig. 3b. The lower SFE of the 25Mn-3Si-1.5Al-NbTi steel results in the presence of the second phase with a lamellar shape, distributed in the austenite matrix (Fig. 4a). The number of annealing twins is much lower. The X-ray diffraction analysis confirms the presence of $\varepsilon$ martensite (Fig. 4b).

a)
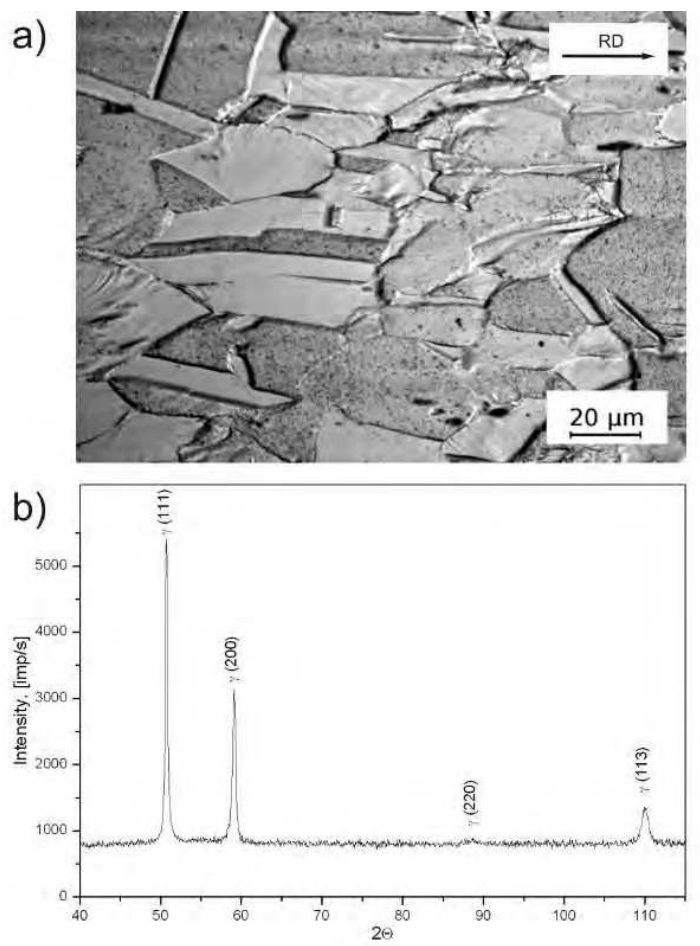

Fig. 3. Austenitic structure with annealing twins of $26 \mathrm{Mn}-3 \mathrm{Si}-3 \mathrm{Al}-\mathrm{Nb}$ steel after the thermomechanical rolling and immersion in $1 \mathrm{~N} \mathrm{H}_{2} \mathrm{SO}_{4}(\mathrm{a})$ and X-ray diffraction pattern (b). 
a)
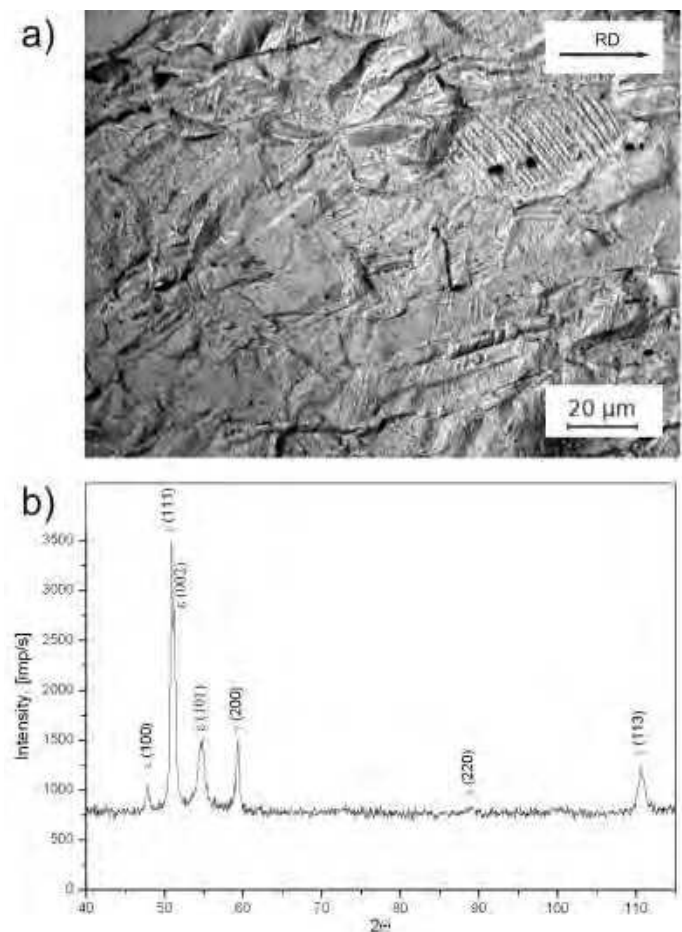

Fig. 4. Austenitic matrix with $\varepsilon$ martensite of $25 \mathrm{Mn}-3 \mathrm{Si}-1.5 \mathrm{Al}-\mathrm{Nb}-\mathrm{Ti}$ steel after the thermomechanical rolling and immersion in $1 \mathrm{~N} \mathrm{H}_{2} \mathrm{SO}_{4}$ (a) and X-ray diffraction pattern (b).

\subsection{Immersion tests}

The immersion tests were used to assess the corrosion resistance of the steels at the initial state (after the thermo-mechanical rolling) and after cold deformation. The corrosion resistance was investigated in two solutions: $1 \mathrm{~N} \mathrm{H}_{2} \mathrm{SO}_{4}$ and $3.5 \mathrm{wt} \% \mathrm{NaCl}$. Prior to the corrosion tests, three samples of the each steel with the size $3.2 \times 10 \times 15 \mathrm{~mm}$ were ground to the 1000-grit finish and then they were washed in distilled water, ultrasonically cleaned in acetone and finally rinsed with ethanol and dried. The specimens were weighed with the accuracy of $0.001 \mathrm{~g}$ and put into the solution for 100 hours at the temperature of $23 \pm 1^{\circ} \mathrm{C}$. After the test the specimens were weighed and analysed using optical microscopy and SEM. Corrosion loss was calculated in a simple way as the difference between final and initial mass of the samples. Percentage mass decrement was also calculated. Cold deformation was applied by bending at room temperature. Samples with a size of 10x15 mm and a thickness of $3.2 \mathrm{~mm}$ were bent to an angle of $90^{\circ}$, with a bending radius of $3 \mathrm{~mm}$.

Metallographic observations of non-metallic inclusions and corrosion pits were carried out on polished sections, whereas the microstructure observations on specimens etched in nital. The investigations were performed using LEICA MEF 4A light microscope, with magnifications from 100 to 1000x. Fractographic investigations were carried using scanning 
electron microscope SUPRA 25 (Zeiss) at the accelerating voltage of $20 \mathrm{kV}$. In order to remove corrosion products, the specimens were ultrasonically cleaned before the analysis.

\subsection{Potentiodynamic polarization tests}

Investigation of the electrochemical corrosion behaviour was done in a PGP 201 potentiostat using a conventional three-electrode cell consisting of a saturated calomel reference electrode (SCE), a platinum counter electrode and the studied specimen as the working electrode. To simulate the corrosion media, $0.5 \mathrm{~N} \mathrm{H}_{2} \mathrm{SO}_{4}$ and $0.5 \mathrm{~N} \mathrm{NaCl}$ solutions were used. The solution temperature was $23^{\circ} \mathrm{C} \pm 1^{\circ} \mathrm{C}$. The corrosion behaviour was studied first by measuring the open circuit potential (OCP) for $30 \mathrm{~min}$. Subsequently, anodic polarization curves were registered. The curve started at a potential of $\sim 100 \mathrm{mV}$ below the corrosion potential. The potential has been changed in the anodic direction at the rate of $1 \mathrm{mV} / \mathrm{s}$. After the anodic current density being equal $1 \mathrm{~mA} / \mathrm{cm}^{2}$ was achieved, the direction of polarization has been changed. Thus, the return curve was registered. The corrosion current densities and the polarization resistance were obtained on the basis of the Tafel analysis.

\section{Results and discussion}

\subsection{Corrosion behaviour in the initial state}

\subsubsection{Results of immersion tests}

The results of the immersion tests in two media are given in Table 2. After 100 hours immersion in $1 \mathrm{~N} \mathrm{H}_{2} \mathrm{SO}_{4}$ both steels showed a significant percentage mass decrement, among 38 and $41 \%$. Mass loss of samples dipped in $3.5 \mathrm{wt} \% \mathrm{NaCl}$ is about 100 times lower. The difference is due to different corrosion mechanisms. When the solution is acidic, the corrosion process is running according to hydrogen depolarization, whereas in chloride media the specimens are corroding with oxygen depolarization.

\begin{tabular}{|c|c|c|}
\hline & \multicolumn{2}{|c|}{ Corrosion medium } \\
\hline Steel grade & $1 \mathrm{~N} \mathrm{H}_{2} \mathrm{SO}_{4}$ & $3.5 \% \mathrm{NaCl}$ \\
\hline $26 \mathrm{Mn}-3 \mathrm{Si}-3 \mathrm{Al}-\mathrm{Nb}$ & $38.4 \pm 5.2$ & $0.40 \pm 0.03$ \\
\hline $25 \mathrm{Mn}-3 \mathrm{Si}-1.5 \mathrm{Al}-\mathrm{Nb}-\mathrm{Ti}$ & $41.3 \pm 9.6$ & $0.48 \pm 0.03$ \\
\hline
\end{tabular}

Table 2. Mean percentage mass loss of samples after the immersion tests, $\%$.

In $26 \mathrm{Mn}-3 \mathrm{Si}-3 \mathrm{Al}-\mathrm{Nb}$ steel immersed in $1 \mathrm{~N} \mathrm{H}_{2} \mathrm{SO}_{4}$ many deep corrosion pits along the whole specimen surface were observed (Fig. 5). Moreover, in places with higher density of nonmetallic inclusions, microcracks locally occur. Similar pits are present in the steel with lower aluminum content. Slightly smaller corrosion pits are formed in specimens after the immersion test in $3.5 \mathrm{wt} \% \mathrm{NaCl}$, regardless of a steel type. Places privileged to creation of corrosion pits are pointwise aggregations and chains of non-metallic inclusions (Fig. 6).

Characteristically for the structure of $25 \mathrm{Mn}-3 \mathrm{Si}-1.5 \mathrm{Al}-\mathrm{Nb}-\mathrm{Ti}$ steel dipped in $3.5 \mathrm{wt} \% \mathrm{NaCl}$ solution are small microcracks located along $\varepsilon$ martensite lamellas (Fig. 7). They are propagated from significantly elongated in a rolling direction, sulphuric non-metallic inclusions. In specimens with the single-phase austenitic structure, microcracks were not observed. 


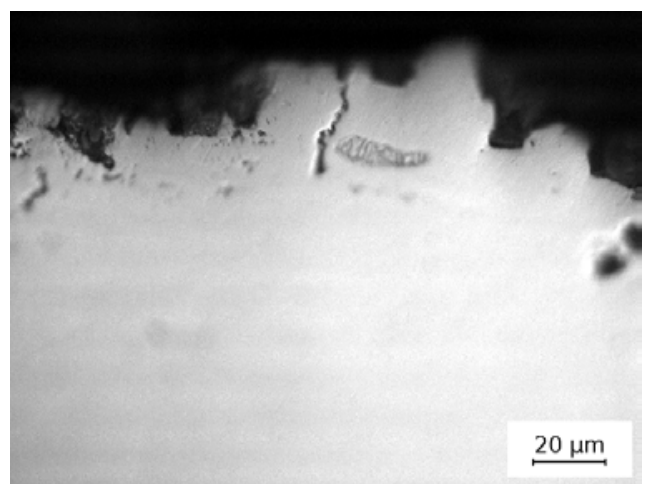

Fig. 5. Corrosion pits and microcracks in $26 \mathrm{Mn}-3 \mathrm{Si}-3 \mathrm{Al}-\mathrm{Nb}$ steel after the immersion test in $1 \mathrm{~N} \mathrm{H}_{2} \mathrm{SO}_{4}$.

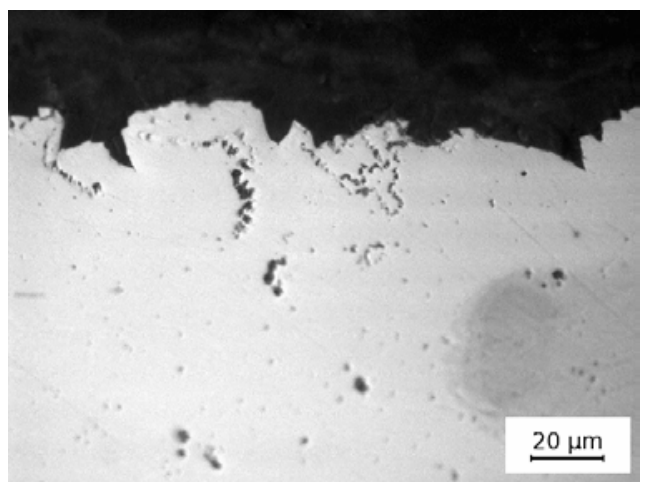

Fig. 6. Corrosion pits in 25Mn-3Si-1.5Al-Nb-Ti steel after the immersion test in $3.5 \mathrm{wt} \% \mathrm{NaCl}$.

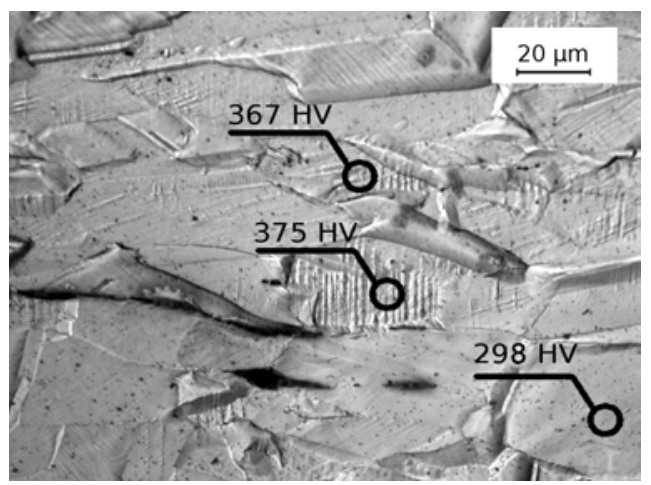

Fig. 7. Austenitic matrix containing plates of $\varepsilon$ martensite and microhardness test results of 25Mn-3Si-1.5Al-Nb-Ti steel.

A precise definition of the character of corrosion damages was possible on the basis of SEM observations. On the surface of specimens of both steels dipped in $\mathrm{NaCl}$ solution, a layer of 
corrosion products is occurring, protecting the metal against further corrosive medium penetration. Created layer includes many cracks, especially in surroundings of non-metallic inclusions (Fig. 8). In case of the specimens dipped in $\mathrm{H}_{2} \mathrm{SO}_{4}$ solution, the number of created surface cracks is much higher (Fig. 9). Apart from corrosion products residues, many craters formed as a result of corrosion pitting. They are occurring both in the steel with $\varepsilon$ martensite lamellas (Fig. 9), as well as in the steel with a single-phase austenitic structure (Fig. 10).

The results confirmed the low corrosion resistance of high-manganese steels in acidic and chloride media. Especially low corrosion resistance the investigated steels show in $1 \mathrm{~N} \mathrm{H}_{2} \mathrm{SO}_{4}$, where the mass decrement is about $40 \%$, what is about 100 times higher than for specimens dipped in $3.5 \mathrm{wt} \% \mathrm{NaCl}$ (Table 2). The similar order of magnitude of corrosion progress was observed for the Fe-0.05C-30Mn-3Al-1.4Si steel (Kannan et al., 2008).

The high difference in corrosion resistance is because of different corrosion mechanisms in both environments. The big mass loss in the $\mathrm{H}_{2} \mathrm{SO}_{4}$ solution is due to the hydrogen depolarization mechanism, which is typical for corrosion in acidic media. Hydrogen depolarization is a process of reducing hydrogen ions (from the electrolyte) in cathodic areas by electrons from the metal, to gaseous hydrogen, resulting in continuous flow of electrons outer the metal and consequently the corrosion progress. Due to this process, numerous corrosion pits occur in examined steels (Figs. 5, 6). Corrosion pits are occurring most intensively in the places containing non-metallic inclusions. They are less precious than the rest of material, fostering potential differences and galvanic cell creation. This causes the absorption of hydrogen ions, which, due to increasing pressure and temperature can recombine to a gaseous form and get out of the metal accompanying formation of corrosion pits (Fig. 10). This process is accompanied by local cracking of corrosion products layer (Figs. 9, 10), uncovering the metal surface and causing further penetration of the corrosive medium and the intensive corrosion progress.

In chloride solution, the corrosion process is running according to the oxygen depolarization. In this mechanism, oxygen included in the electrolyte is being reduced by electrons from the metal to hydroxide ions. On the surface of the alloy appears a layer of corrosion products (Fig. 8), protecting the material before further penetration of the corrosion medium. This is why the mass loss in chloride solution is much lower compared to acidic medium. At less corrosion-resistant places (e.g. with non-metallic inclusions) potential differences are occurring. This enables the absorption of chloride ions, which are forming chlorine oxides of increased solubility. This results in local destructions of corrosion products layer (Fig. 8) and the initiation of corrosion pits. Further pit expansion is running autocatalytic.

As a consequence of small steel softening during static recrystallization (Grajcar \& Borek, 2008; Grajcar et al., 2009) after finishing rolling, the state of internal stresses in examined steels can be increased. In specimen areas with internal stresses, crevices are occurring. Due to limited oxygen access and a lack of possibility of corrosion products layer forming, they become susceptible to corrosion. As a result of chloride ions adsorption on the crevice bottom, a concentrated electrolyte solution is forming, fostering the corrosion progress (Cottis \& Newman, 1995). As a result, stress corrosion cracking can take place. Microcracks were observed along $\varepsilon$ martensite lamellas in $25 \mathrm{Mn}-3 \mathrm{Si}-1.5 \mathrm{Al}-\mathrm{Nb}-\mathrm{Ti}$ steel. The microcracks initiation proceeds in places with elongated non-metallic inclusions (Fig. 7), while their propagation runs along plates of the second phase. 


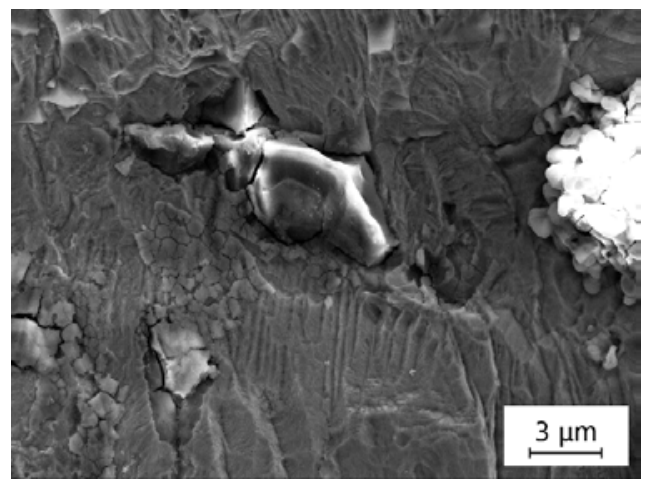

Fig. 8. Bursted corrosion products layer on $26 \mathrm{Mn}-3 \mathrm{Si}-3 \mathrm{Al}-\mathrm{Nb}$ steel surface after the immersion test in $3.5 \mathrm{wt} \% \mathrm{NaCl}$.

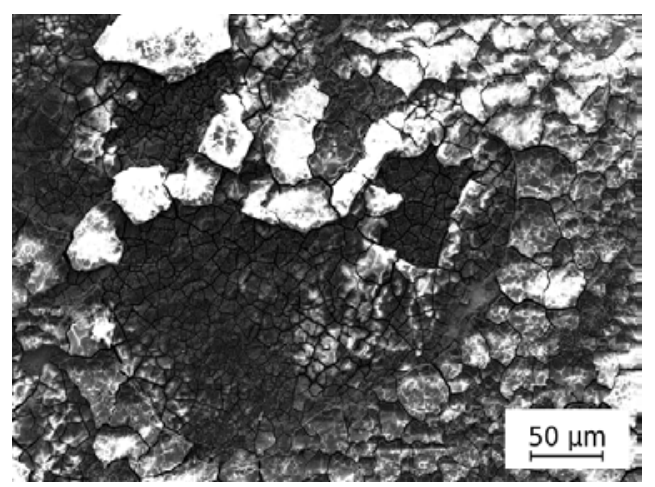

Fig. 9. Craters created as a result of corrosion pitting and bursted corrosion products layer in $25 \mathrm{Mn}-3 \mathrm{Si}-1.5 \mathrm{Al}-\mathrm{Nb}-\mathrm{Ti}$ steel after the immersion test in $1 \mathrm{~N} \mathrm{H}_{2} \mathrm{SO}_{4}$.

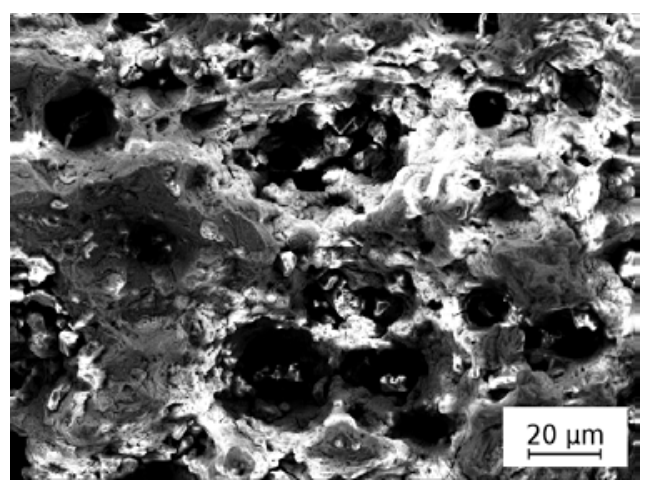

Fig. 10. Craters created as a result of corrosion pitting and corrosion products residues in $26 \mathrm{Mn}-3 \mathrm{Si}-3 \mathrm{Al}-\mathrm{Nb}$ steel after the immersion test in $1 \mathrm{~N} \mathrm{H}_{2} \mathrm{SO}_{4}$. 
The mass decrement in two steels is comparable (Table 2) both in acidic and chloride media. It indicates that a small $\varepsilon$ martensite fraction does not have meaningful impact on the corrosion progress. The observed corrosion products are related rather to the chemical composition than to the phase structure of investigated steels. That confirms a slightly higher mass decrement in the steel with lower $\mathrm{Al}$ and somewhat higher Si content. In general, the low corrosion resistance of high-manganese steels is from the fact, that $\mathrm{Mn}$ in steels forms unstable manganese oxide due to low passivity coefficient and hence reduces their electrochemical corrosion resistance (Kannan et al., 2008). It leads consequently to the high dissolution rate of manganese and iron atoms both in $\mathrm{H}_{2} \mathrm{SO}_{4}$ and $\mathrm{NaCl}$ solutions (Ghayad et al., 2006; Hamada, 2007; Kannan et al., 2008; Zhang \& Zhu, 1999).

The high mass decrement of steels examined in $\mathrm{H}_{2} \mathrm{SO}_{4}$ solution is a result of fast general corrosion progress and corrosion pits formation (Figs. 5, 6). Much lower mass loss in steels examined in $\mathrm{NaCl}$ solution is connected mainly with corrosion pits forming (Fig. 6). The presence of corrosion pits in chloride medium in steels of the type Fe-25Mn-5Al and Fe0.2C-25Mn-(1-8)Al was also confirmed by other authors (Hamada, 2007; Zhang \& Zhu, 1999). However, significant participation of pitting corrosion was not observed in the studies on Fe-0.05C-29Mn-3.1Al-1.4Si steel (Kannan et al., 2008) and on Fe-0.5C-29Mn-3.5Al0.5Si steel (Ghayad et al., 2006). Localized corrosion attack in the presently investigated steels is enhanced by the lower aluminium and higher silicon concentrations. It means that a character of corrosion damages in high-manganese steels in chloride medium is a complex reaction of the chemical composition and structural state related with a phase composition and the degree of strain hardening.

\subsubsection{Results of potentiodynamic polarization tests}

Electrochemical corrosion resistance in potentiodynamic tests was carried out on the steel characterized by two-phase structure after the thermo-mechanical rolling. The change of current density as a function of potential for the sample investigated in $0.5 \mathrm{~N} \mathrm{NaCl}$ solution is presented in Fig. 11. The value of corrosion potential was equal $-796 \mathrm{mV}$ and the corrosion current density was $8.4 \mu \mathrm{A} / \mathrm{cm}^{2}$. Determination of pitting potential was impossible due to the fast course of corrosion processes. It is clear in Fig. 11 that the passivation did not occur. The factors which precluded repassivation inside pits being formed on the surface of the sample were probably the increase of chloride ions concentration as a consequence of their relocation along the corrosion current, what made the contribution to the formation of a corrosion cell inside the pit as well as difficult supply of oxygen into the interior of the pit because of its low solubility in the electrolyte. The change of polarization of samples did not cause any decrease of anodic current.

The corrosion potential of the $25 \mathrm{Mn}-3 \mathrm{Si}-1.5 \mathrm{Al}-\mathrm{Nb}$-Ti steel investigated in $0.5 \mathrm{~N} \mathrm{H}_{2} \mathrm{SO}_{4}$ is equal to $-574 \mathrm{mV}$ (Fig. 12). It is shifted towards the more noble direction, as compared to chloride solution. However, the corrosion current density is equal to about $3400 \mu \mathrm{A} / \mathrm{cm}^{2}$, what is over two orders of magnitude higher compared to chloride solution.

The similar values of the corrosion potential and corrosion current density both in chloride and acidic media are reported by other authors (Ghayad et al., 2006; Kannan et al., 2008). The sample gains no passivation and the pitting potential was about $57 \mathrm{mV}$ (Fig. 12). It is 
interesting to note the fast increase of corrosion current after the initiation of pitting corrosion. The escalation of corrosion current usually is more mild.

Fractographic analyses of sample surface after the corrosion tests allowed to evaluate the type and the degree of corrosion damages. On the surface of samples investigated in $0.5 \mathrm{~N}$ $\mathrm{NaCl}$ numerous relatively small corrosion pits and micropores were revealed (Figs. 13, 14). Damaging of a superficial layer occurred around the pits. Cracked passive layer was also observed, what could be a result of rapid penetration of corrosive medium into interior of investigated specimens (Fig. 14). Similar corrosion effects, i.e. pitting, cracked interfacial layer and scaled surface were identified in the specimens after electrochemical tests in $0.5 \mathrm{~N}$ $\mathrm{H}_{2} \mathrm{SO}_{4}$ solution (Figs. 15, 16). The results correspond well with those obtained after immersion tests.

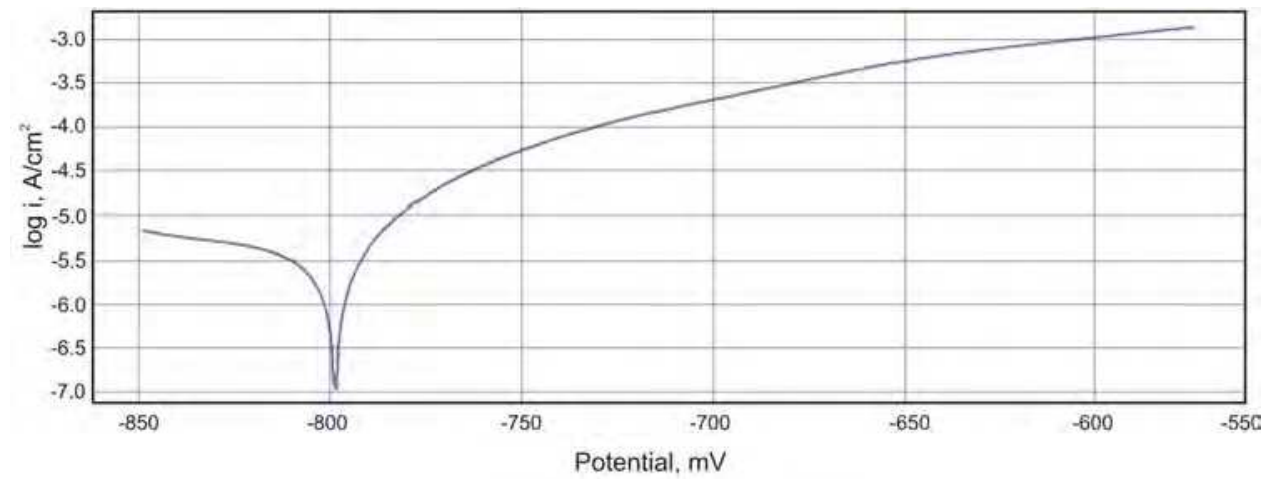

Fig. 11. Anodic polarization curve registered for the sample of 25Mn-3Si-1.5Al-Nb-Ti steel in $0.5 \mathrm{~N} \mathrm{NaCl}$.

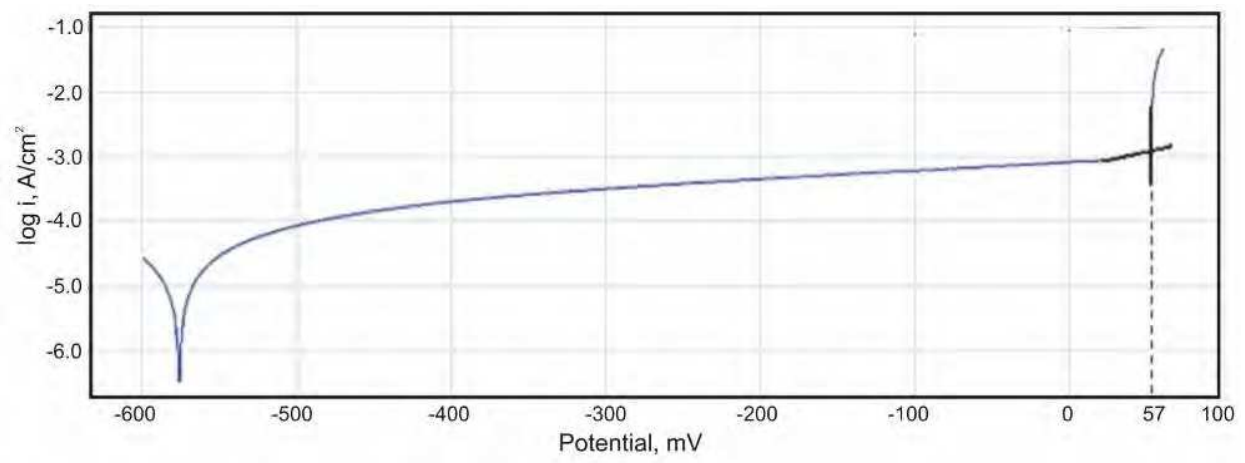

Fig. 12. Anodic polarization curve registered for the sample of 25Mn-3Si-1.5Al-Nb-Ti steel in $0.5 \mathrm{~N} \mathrm{H}_{2} \mathrm{SO}_{4}$. 


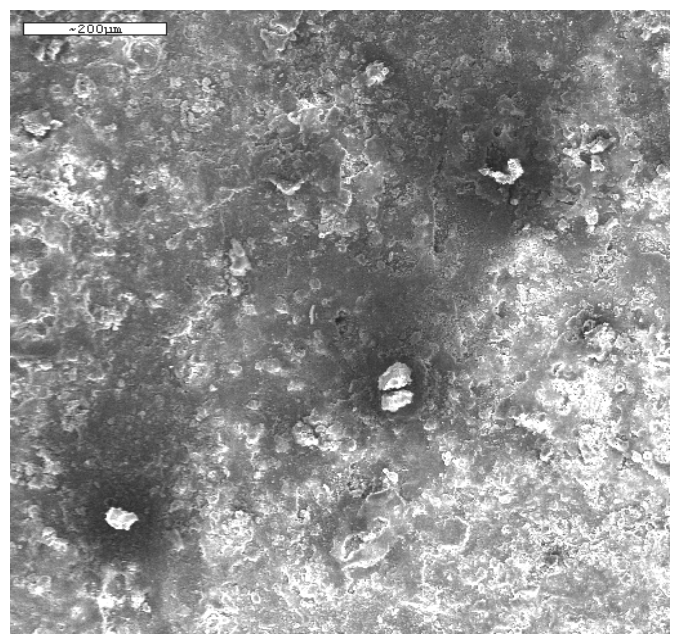

Fig. 13. Numerous corrosion pits on the surface of the specimen after electrochemical tests in $0.5 \mathrm{~N} \mathrm{NaCl}$.

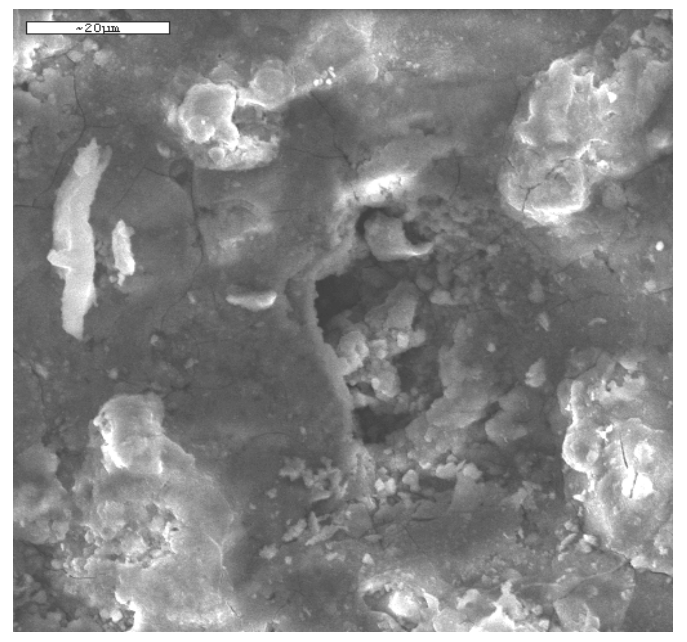

Fig. 14. Corrosion pitting on the surface of the specimen after electrochemical tests in $0.5 \mathrm{~N}$ $\mathrm{NaCl}$. 


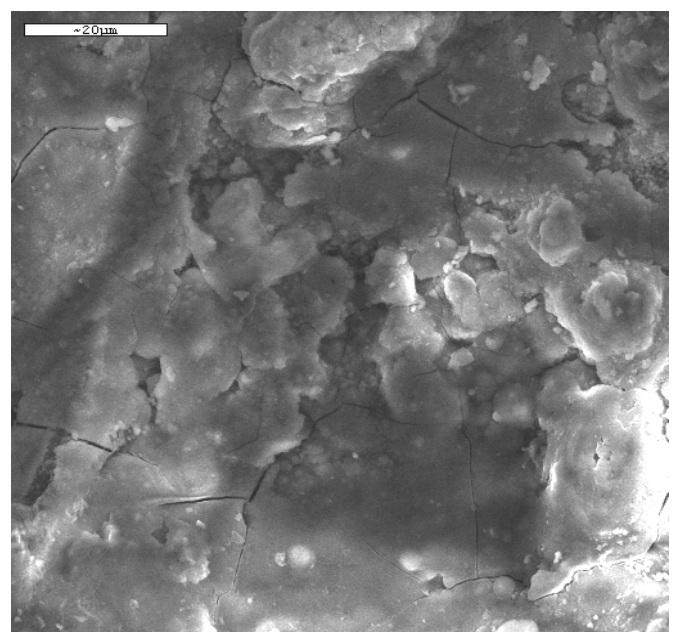

Fig. 15. Scaled and partially cracked surface of the specimen after electrochemical tests in the $0.5 \mathrm{~N} \mathrm{H}_{2} \mathrm{SO}_{4}$.

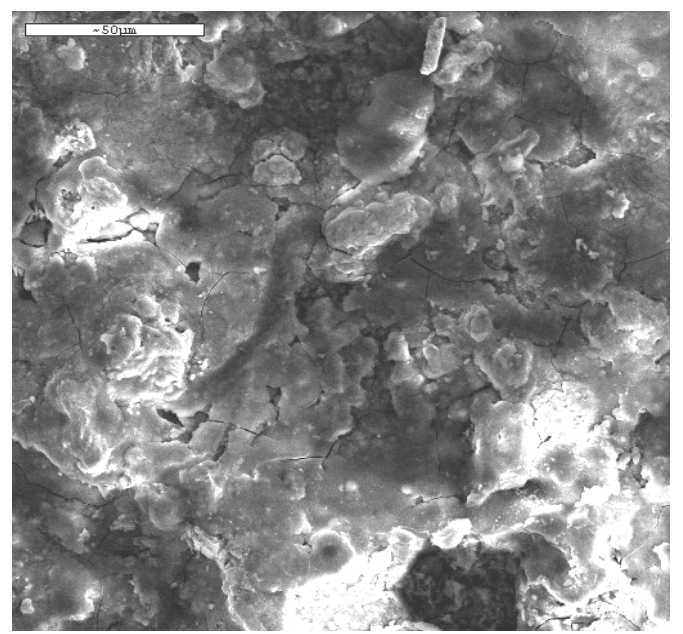

Fig. 16. Scaled surface and corrosion pits of the specimen after corrosion tests in the $0.5 \mathrm{~N}$ $\mathrm{H}_{2} \mathrm{SO}_{4}$.

\subsection{Corrosion behaviour in the cold-worked state}

In both steels, immersed after deformation in $1 \mathrm{~N} \mathrm{H}_{2} \mathrm{SO}_{4}$ many corrosion pits of various size were observed (Fig. 17). The amount and the size of pits are very high and they are formed along the entire surface of specimens. Privileged places to pits forming are surface concentrations of non-metallic inclusions, which are also probable place of hydrogen penetration. Hydrogen also penetrates deeper into the steel - probably by $\varepsilon$ martesite plates - accumulating in a surroundings of elongated non-metallic sulfide inclusions (Fig. 18). 
Hydrogen failures were usually observed to the depth of about $0.3 \mathrm{~mm}$. Places of hydrogen accumulation are also visible on samples revealing the steel structure after cold deformation. Usually, these places are elongated non-metallic inclusions, grain boundary areas and/or twin boundaries (Fig. 19). The 26Mn-3Si-3Al-Nb steel keeps after plastic deformation the austenitic structure, whereas a fraction of martensite in $25 \mathrm{Mn}-3 \mathrm{Si}-1.5 \mathrm{Al}-\mathrm{Nb}-$ Ti steel increases (Fig. 20).

Besides non-metallic inclusions, especially privileged to hydrogen accumulation are lamellar areas of $\varepsilon$ martensite. Absorbed atomic hydrogen penetrating the steel, accumulates in places with non-metallic inclusions, lamellar precipitations of the second phase, microcracks and other structural defects, where convenient conditions for recombining of atomic hydrogen to molecular $\mathrm{H}_{2}$ exist. The recombination of atomic hydrogen to molecular state is a very exothermic reaction, which provides a pressure increase in formed $\mathrm{H}_{2}$ bubbles as well as nucleation and growth of microcracks in a surface region of the sample (Fig. 20).

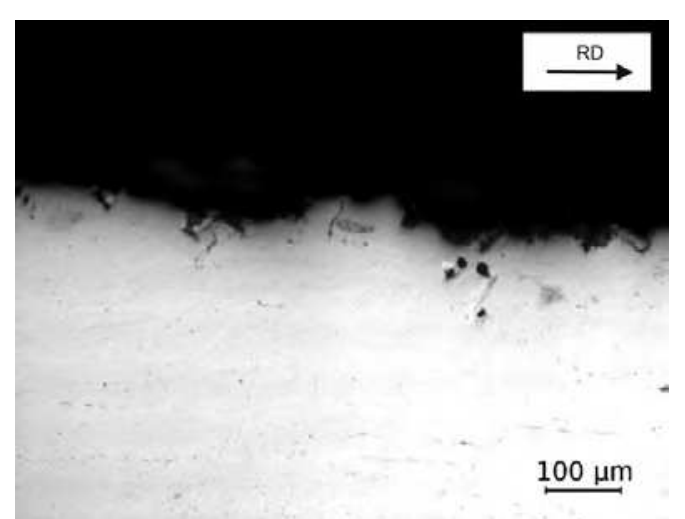

Fig. 17. Wide corrosion pits on the surface of $26 \mathrm{Mn}-3 \mathrm{Si}-3 \mathrm{Al}-\mathrm{Nb}$ steel immersed in $1 \mathrm{~N}_{2} \mathrm{SO}_{4}$ and probable places of hydrogen penetration (transverse section).

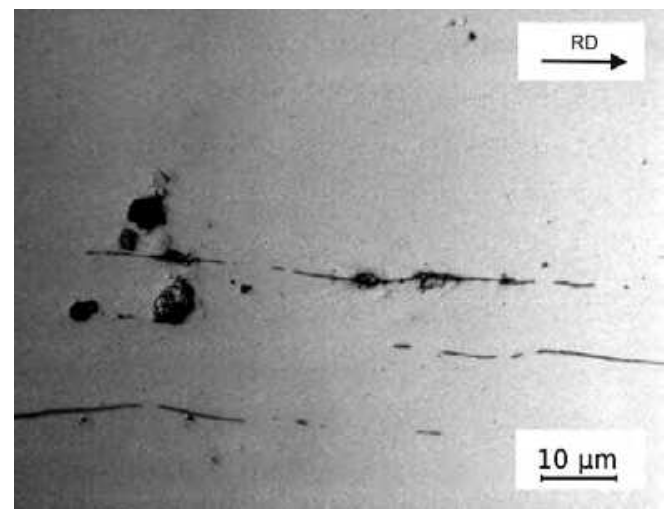

Fig. 18. Regions of hydrogen accumulation around elongated sulfide-type non-metallic inclusions in 25Mn-3Si-1.5Al-Nb-Ti steel (transverse section). 


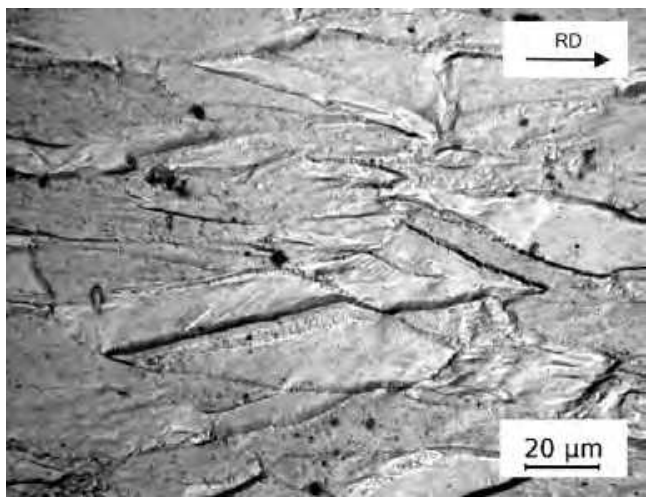

Fig. 19. Elongated austenite grains of $26 \mathrm{Mn}-3 \mathrm{Si}-3 \mathrm{Al}-\mathrm{Nb}$ steel after cold deformation and some places of hydrogen accumulation (transverse section).

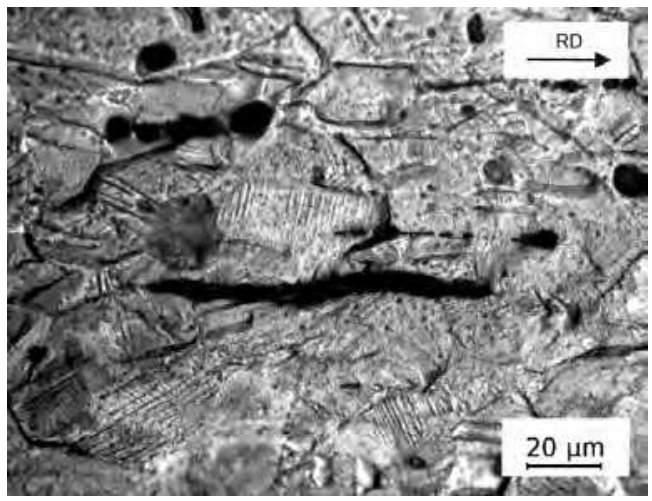

Fig. 20. Regions of hydrogen failures and hydrogen microcracks in 25Mn-3Si-1.5Al-Nb-Ti steel, plastically deformed and immersed in $1 \mathrm{~N} \mathrm{H}_{2} \mathrm{SO}_{4}$ (transverse section).

After bending and 100 hours immersion in $1 \mathrm{~N} \mathrm{H}_{2} \mathrm{SO}_{4}$ both steels show a meaningful percentage mass decrement, among 47 and $49 \%$ and 2 orders of magnitude lower in chloride solution (Table 3). Cold deformation rises slightly the mass decrement in acidic medium, in comparison with the specimens investigated in undeformed state (Table 2). The opposite is true for chloride solution. However, the differences are not significant. Comparable mass loss of two steels both in non-deformed and plastically deformed states indicates that the initial structure does not have meaningful impact on the corrosion progress.

\begin{tabular}{|c|c|c|}
\hline & \multicolumn{2}{|c|}{ Corrosion medium } \\
\hline Steel grade & $1 \mathrm{~N} \mathrm{H}_{2} \mathrm{SO}_{4}$ & $3.5 \% \mathrm{NaCl}$ \\
\hline $26 \mathrm{Mn}-3 \mathrm{Si}-3 \mathrm{Al}-\mathrm{Nb}$ & $47.5 \pm 1.6$ & $0.33 \pm 0.01$ \\
\hline $25 \mathrm{Mn}-3 \mathrm{Si}-1.5 \mathrm{Al}-\mathrm{Nb}-\mathrm{Ti}$ & $49.5 \pm 2.4$ & $0.37 \pm 0.12$ \\
\hline
\end{tabular}

Table 3. Mean percentage mass loss of cold-deformed samples after the immersion tests, $\%$ 
Figures 21-23 present the SEM microstructures of plastically deformed samples immersed in acidic solution. It is characteristic that corrosion cracks were not observed, whereas deep corrosion damages and band arranged corrosion products can be perceived (Fig. 21). The corrosion products layer is not continuous and has many cracks (Fig. 22). Besides remaining corrosion products, a numerous number of craters, created due to intensive corrosion pitting and probably as a result of hydrogen impact, is characteristic. Craters forming is accompanied by local cracking of corrosion products layer (Figs. 21, 22), uncovering the metal surface and causing further penetration of the corrosive medium and finally the intensive progress of general and pitting corrosion.

Hydrogen Induced Cracking (HIC) is a problem in carbon steels and especially in highstrength low-alloy steels. Typical examples are hydrogen failures of gas pipelines containing hydrogen sulfide (Cottis \& Newman, 1995; Ćwiek, 2009). Conventional Cr-Ni austenitic steels are not usually liable to such damages. One of the reasons is relatively low diffusion coefficient of hydrogen in austenite as distinguished from steels with ferritic or martensitic structures (Kumar \& Balasubramaniam, 1997; Xu et al., 1994). However, enhanced permeation of hydrogen was observed in cold worked austenitic steels what was attributed to strain-induced martensitic transformation leading to promote hydrogen diffusion as the diffusivity is much higher in the bcc martensite lattice (Kumar \& Balasubramaniam, 1997). The hydrogen induced surface cracking at the high hydrogen concentration places, i.e. grain and twin boundaries, $\varepsilon / \gamma$ interface was also observed in $\mathrm{Cr}-\mathrm{Ni}$ steels during hydrogen effusion from the supersaturated sites (Yang \& Luo, 2000). Additionally, hydrogen mobility is enhanced by the presence of high-dislocation density due to cold working (Ćwiek, 2009). It is important to note that hydrogen impact occurs both in diphase (Figs. 18, 20) and single phase (Figs. 10, 23) structures of the steels.

In the investigated high-Mn austenitic steels the high corrosion progress and uncovering of metal surface by formed successively corrosion pits (Figs. 17, 23) should be taken into account. Uncovered active metal inside of expanding pits reacts with the acidic solution with hydrogen emission. In this regard hydrogen impact can influence the corrosion behaviour of the investigated steels. Indirect confirmation of this fact are numerous craters formed due to corrosion pitting and probably hydrogen impact (Figs. 10, 23). The effect of hydrogen can be further enhanced by the presence of increased sulphur concentration (for example present as sulfide non-metallic inclusions).

On the surface of specimens dipped in $\mathrm{NaCl}$ solution, a layer of corrosion products, which protects the metal against continuous penetration of corrosive media, is forming. Created scaled layer strongly adheres to the base, though numerous surface cracks (Fig. 24). There are many corrosion cracks running from the specimen surface with a maximum value of inner stresses in the steel with martensite plates (Fig. 25). Rectilinear course of cracks, shows the transcrystalline cracking character, to which austenitic steels in media with chloride ions are sensitized. Corrosion cracks were not present in the steel with single-phase austenitic matrix. A few microcracks along martensite lamellas were also revealed (Fig. 26). The microcracks were usually nucleated on elongated non-metallic inclusions and were spread along martensitic plates with a hardness higher compared to the austenitic matrix (Grajcar et al., 2010a). 


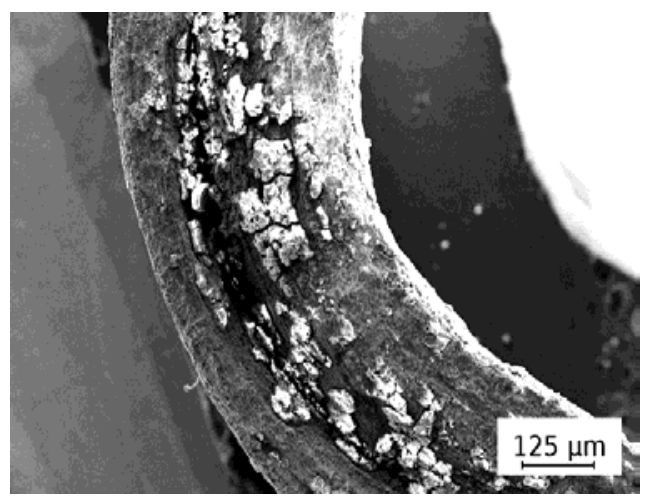

Fig. 21. Deep corrosion decrements and banding-like arrangement of corrosion products in 26Mn-3Si-3Al-Nb steel, plastically deformed and immersed in $1 \mathrm{~N}_{2} \mathrm{SO}_{4}$.

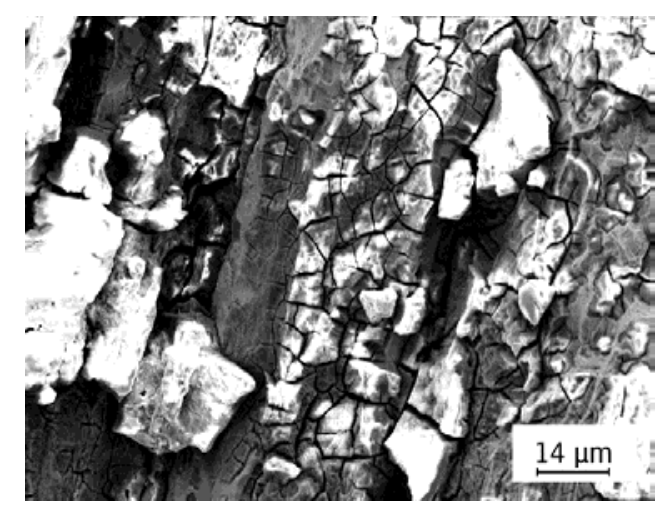

Fig. 22. Cracked layer of corrosion products with banding-like arrangement in 25Mn-3Si1.5Al-Nb-Ti steel, plastically deformed and immersed in $1 \mathrm{~N}_{2} \mathrm{SO}_{4}$.

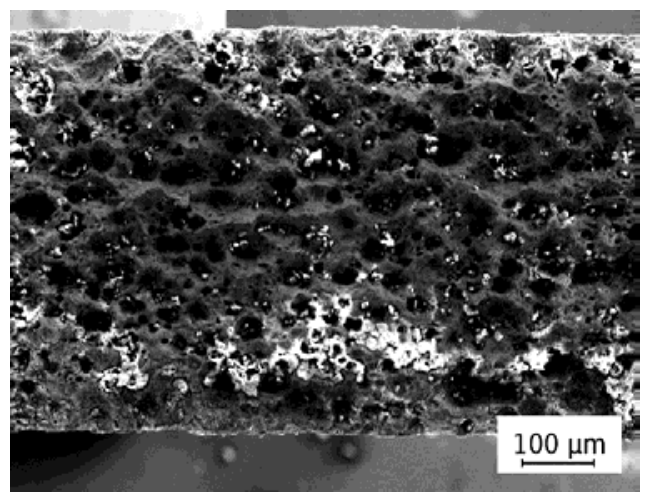

Fig. 23. Numerous craters formed due to corrosion pitting and probable hydrogen penetration in $26 \mathrm{Mn}-3 \mathrm{Si}-3 \mathrm{Al}-\mathrm{Nb}$ steel, plastically deformed and immersed in $1 \mathrm{~N} \mathrm{H}_{2} \mathrm{SO}_{4}$. 


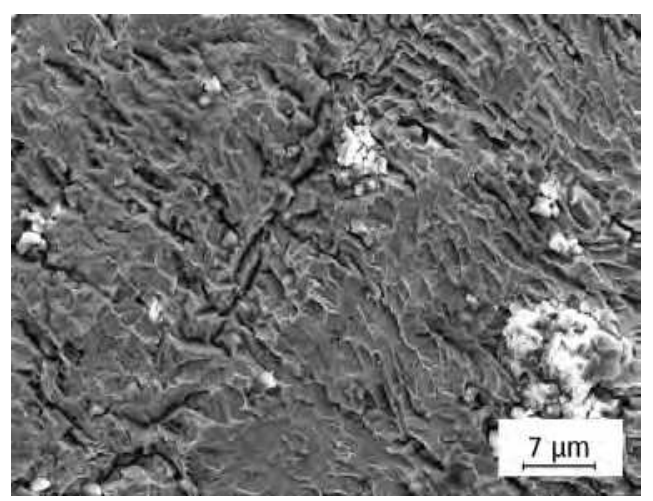

Fig. 24. Scaled and cracked layer of corrosion products in 25Mn-3Si-1.5Al-Nb-Ti steel, plastically deformed and immersed in $3.5 \mathrm{wt} \% \mathrm{NaCl}$.

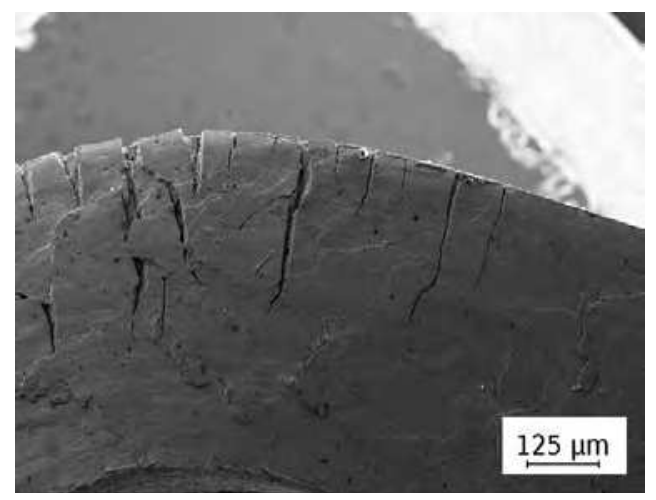

Fig. 25. Deep corrosion cracks in 25Mn-3Si-1.5Al-Nb-Ti steel after bending and the immersion in $3.5 \mathrm{wt} \% \mathrm{NaCl}$.

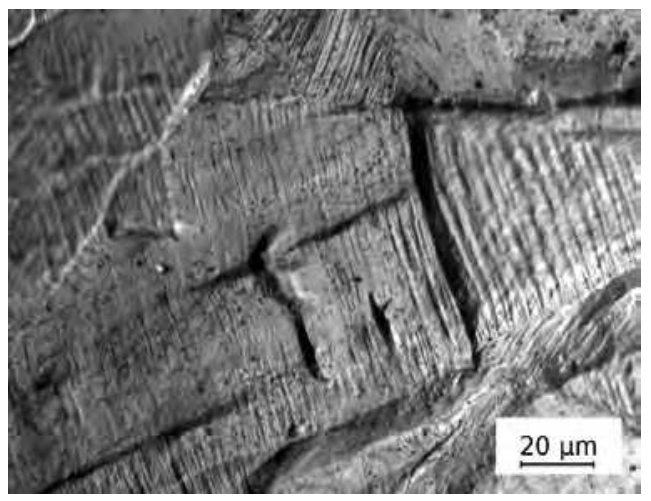

Fig. 26. Microcracks running from non-metallic inclusions along hard martensitic plates in 25Mn-3Si-1.5Al-Nb-Ti steel, plastically deformed and immersed in 3.5wt $\% \mathrm{NaCl}$. 


\section{Summary}

The automotive industry still requires steel sheets with higher strength, ductility and technological formability. Recently, special pressure is put to the need of increasing the passive safety of passengers what can be met by using specially designed controlled crash zones absorbing the energy during crash events. High-manganese austenitic alloys satisfy these requirements. However, the main disadvantage is their relatively poor corrosion resistance.

The results presented in this study focused on the evaluation of corrosion resistance of two high-Mn steels of the different initial structure in acidic and chloride media. The investigations were carried out on the specimens after the thermo-mechanical rolling and after cold deformation. The results of immersion and potentiodynamic tests as well as structural analysis prove that both examined steels, independent of initial structure, have very low corrosion resistance in acidic medium and low corrosion resistance in chloride solution. In particular it was found that:

- the mass decrement of specimens immersed in $1 \mathrm{~N} \mathrm{H}_{2} \mathrm{SO}_{4}$ for 100 hours is equal about $40 \%$ and is about 100 higher compared to the specimens immersed in $3.5 \mathrm{wt} \% \mathrm{NaCl}$; The percentage mass loss of plastically deformed specimens is slightly higher compared to non-deformed specimens in acidic solution and slightly lower in chloride medium;

- the percentage mass decrement in the steel with single-phase austenitic structure is slightly lower than in the steel with $\varepsilon$ martensite lamellas. However, any significant impact of the second phase on corrosion process acceleration was not observed;

- the decisive impact on the corrosion resistance of examined steels has their chemical composition, which determines the high rate of manganese and iron dissolution in acidic solution. The oxygen depolarization process results in formation of corrosion products layer on the surface of the steel examined in chloride medium. Therefore, the mass decrement of steels in $3.5 \mathrm{wt} \% \mathrm{NaCl}$ is much lower than in $1 \mathrm{~N} \mathrm{H}_{2} \mathrm{SO}_{4}$;

- both steels are liable to general and pitting corrosion, especially intensively in the sulfuric acid solution. A very adverse influence on corrosion pitting initiation has a relative large fraction of non-metallic inclusions, especially of these forming local aggregations. In chloride solution it also results in occurring local microcracks, nucleating at elongated non-metallic inclusions and growing along hard martensite plates;

- the surface layer of band-arranged corrosion products located accordingly to the deformation direction has many cracks, especially in surroundings of corrosion pits and non-metallic inclusions. In case of acidic solution, the cracks are also formed round craters formed due to corrosion pitting;

- the craters identified in both steels examined in acidic medium are combined effect of various corrosion damages in high-Mn austenitic steels. Hydrogen impact is the additional effect accompanying general corrosion and corrosion pits forming. Its influence is enhanced by numerous corrosion pits, sulfide non-metallic inclusions and martensite plates of high hardness;

- mechanical twins formed during cold working in the single-phase austenitic steel accelerate the corrosion progress. However, the special care should concern the steels containing $\varepsilon$ martensite plates (in the initial structure, strain-induced or hydrogeninduced), which are especially susceptible to surface cracking in hydrogen containing solution and to corrosion cracking in chloride solution. 
The corrosion resistance in chloride solutions in high-Mn alloys containing aluminum can be improved by the anodic passivation in $30 \% \mathrm{HNO}_{3}$ aqueous solution (Hamada et al., 2005). It leads to the modification of the chemical composition of the surface layer, connected with reducing the manganese concentration at the surface layer and the enrichment this region in $\mathrm{Al}$, improving the corrosion resistance. Another way of improving the corrosion resistance of high-manganese steels is to use zinc coatings. Due to alloying problems, the use of the electro-galvanizing process is promising (Hamada, 2007). The best solution seems to be the incorporation of $\mathrm{Cr}$, which promotes the formation of a passivation layer and improves the corrosion resistance (Hamada, 2007; Mujica et al., 2010). However, the changes in SFE of austenite by $\mathrm{Cr}$ and the resulting main deformation mechanism should be taken into account. Some chemical composition strategies include alloys with increased nitrogen concentration, which improves the resistance to pitting corrosion (Mujica Roncery et al., 2010).

\section{Acknowledgement}

The author would like to thank to Dr. Wojciech Krukiewicz, Dr. Marek Opiela, Mr. Sławomir Kołodziej for carrying out some corrosion experiments and to Dr. Witold Walke for his fruitful discussion.

\section{References}

Altstetter, C.J.; Bentley, A.P.; Fourine, J.W. \& Kirkbridge, A.N. (1986). Processing and properties of Fe-Mn-Al alloys. Materials Science and Engineering A, Vol.82 (1986), pp. 13-25

Bleck, W. \& Phiu-on, K. (2005). Microalloying of cold-formable multi phase steel grades. Materials Science Forum, Vol.500-501, (2005), pp. 97-112

Bleck, W.; Phiu-on, K.; Herring, C., \& Hirt, G. (2007). Hot workability of as-cast high manganese high-carbon steels. Steel Research International, Vol.78, No.7, (2007), pp. 536-545

Cabanas, N.; Akdut, N.; Penning, J. \& De Cooman, B.C. (2006). High-temperature deformation properties of austenitic Fe-Mn alloys. Metallurgical and Materials Transactions A, Vol.37A, (2006), pp. 3305-3315

Cottis, R.A. \& Newman, R.C. (1995). Stress corrosion cracking resistance of duplex stainless steels, HSE Books, ISBN 0-7176-0915-4, London, UK

Ćwiek, J. (2009). Hydrogen degradation of high-strength steels. Journal of Achievements in Materials and Manufacturing Engineering, Vol.37, (2009), pp. 193-212

De Cooman, B.C.; Chin, K. \& Kim, J. (2011). High Mn TWIP steels for automotive applications, In: New trends and developments in automotive system engineering, M. Chiaberge, (Ed.), pp. 101-128, InTech, ISBN 978-953-307-517-4, Rijeka, Croatia

Dini, G.; Najafizadeh, A.; Ueji, R. \& Monir-Vaghefi S.M. (2010). Tensile deformation behavior of high manganese austenitic steel: The role of grain size. Materials and Design, Vol.31, (2010), pp. 3395-3402

Dobrzański, L.A.; Grajcar, A. \& Borek, W. (2008). Microstructure evolution and phase composition of high-manganese austenitic steels. Journal of Achievements in Materials and Manufacturing Engineering, Vol.31, (2008), pp. 218-225 
Dumay, A.; Chateau, J.P.; Allain, S.; Migot, S. \& Bouaziz, O. (2008). Influence of addition elements on the stacking-fault energy and mechanical properties of an austenitic Fe-Mn-C steel. Materials Science and Engineering, Vol.483-484, (2008), pp. 184-187

Frommeyer, G. \& Bruex, U. (2006). Microstructures and mechanical properties of highstrength Fe-Mn-Al-C light-weight TRIPLEX steels. Steel Research International, Vol.77, No.9-10, (2006), pp. 627-633

Frommeyer, G.; Bruex, U. \& Neumann, P. (2003). Supra-ductile and high-strength manganese-TRIP/TWIP steels for high energy absorption purposes. ISIJ International, Vol.43, No.3, (2003), pp. 438-446

Ghayad, I.M.; Hamada, A.S.; Girgis, N.N. \& Ghanem, W.A. (2006). Effect of cold working on the aging and corrosion behaviour of Fe-Mn-Al stainless steel. Steel Grips, Vol.4, No.2, (2006), pp. 133-137

Graessel, O.; Krueger, L.; Frommeyer, G. \& Meyer, L.W. (2000). High strength Fe-Mn-(Al, Si) TRIP/TWIP steels development - properties - application. International Journal of Plasticity, Vol.16, (2000), pp. 1391-1409

Grajcar, A. \& Borek, W. (2008). The thermo-mechanical processing of high-manganese austenitic TWIP-type steels. Archives of Civil and Mechanical Engineering, Vol.8, No.4, (2008), pp. 29-38

Grajcar, A.; Kołodziej, S. \& Krukiewicz, W. (2010a). Corrosion resistance of high-manganese austenitic steels. Archives of Materials Science and Engineering, Vol.41, No.2, (2010), pp. $77-84$

Grajcar, A.; Krukiewicz, W. \& Kołodziej, S. (2010b). Corrosion behaviour of plastically deformed high-Mn austenitic steels. Journal of Achievements in Materials and Manufacturing Engineering, Vol.43, No.1, (2010), pp. 228-235

Grajcar, A.; Opiela, M. \& Fojt-Dymara, G. (2009). The influence of hot-working conditions on a structure of high-manganese steel. Archives of Civil and Mechanical Engineering, Vol.9, No.3, (2009), pp. 49-58

Hamada, A.S. (2007). Manufacturing, mechanical properties and corrosion behaviour of high-Mn TWIP steels, Acta Universitatis Ouluensis C281, ISBN 978-951-42-8583-7, Oulu, Finland

Hamada, A.S.; Karjalainen, L.P. \& El-Zeky, M.A. (2005). Effect of anodic passivation on the corrosion behaviour of $\mathrm{Fe}-\mathrm{Mn}-\mathrm{Al}$ steels in $3.5 \% \mathrm{NaCl}$, Proceedings of the $9^{\text {th }}$ International Symposium on the Passivation of Metals and Semiconductors and the Properties of Thin Oxide Layers, pp. 77-82, Paris, France, June 27-30, 2005

Huang, B.X.; Wang, X.D.; Rong, Y.H.; Wang, L. \& Jin, L. (2006). Mechanical behavior and martensitic transformation of an Fe-Mn-Si-Al-Nb alloy. Materials Science and Engineering A, Vol.438-440, (2006), pp. 306-313

International Iron \& Steel Institute (September 2006). Advanced High Strength Steel (AHSS) Application Guidelines - version 3, Available from http://worldautosteel.org

Jimenez, J.A. \& Frommeyer, G. (2010). Microstructure and texture evolution in a high manganese austenitic steel during tensile test. Materials Science Forum, Vol.638-642, (2010), pp. 3272-3277

Kannan, M.B.; Raman, R.K.S., \& Khoddam, S. (2008). Comparative studies on the corrosion properties of a Fe-Mn-Al-Si steel and an interstitial-free steel. Corrosion Science, Vol.50, (2008), pp. 2879-2884 
Kumar, P. \& Balasubramaniam, R. (1997). Determination of hydrogen diffusivity in austenitic stainless steels by subscale microhardness profiling. Journal of Alloys and Compounds, Vol.255, (1997), pp. 130-134

Lovicu, G.; Barloscio, M.; Botaazzi, M.; D'Aiuto, F.; De Sanctis, M.; Dimatteo, A.; Federici, C.; Maggi, S.; Santus, C. \& Valentini, R. (2010). Hydrogen embrittlement of advanced high strength steels for automotive use. Proceedings of International Conference on Super-High Strength Steels, pp. 1-13, Peschiera del Garda, Italy, October 17-20, 2010

Mazancova, E.; Kozelsky, P. \& Schindler, I. (2010). The TWIP alloys resistance in some corrosion reagents. Proceedings of International Conference METAL, pp. 1-6, Roznov pod Radhostem, Czech Republic, May 18-20, 2010

Mujica, L.; Weber, S. \& Theisen, W. (2010). Development of high-strength corrosion-resistant austenitic TWIP steel. Proceedings of International Conference on Super-High Strength Steels, pp. 1-9, Peschiera del Garda, Italy, October 17-20, 2010

Mujica Roncery, L.; Weber, S. \& Theisen, W. (2010). Development of Mn-Cr-(C-N) corrosion resistant twinning induced plasticity steels: thermodynamic and diffusion calculations, production and characterization. Metallurgical and Materials Transactions A, Vol.41A, No.10, (2010), pp. 2471-2479

Opiela, M.; Grajcar, A. \& Krukiewicz, W. (2009). Corrosion behaviour of Fe-Mn-Si-Al austenitic steel in chloride solution. Journal of Achievements in Materials and Manufacturing Engineering, Vol.33, No.2, (2009), pp. 159-165

Otto, M.; John, D.; Schmidt-Juergensen R.; Springub, B.; Cornelissen, M.; Berkhout, B.; Bracke, L. \& Patel, J. (2010). HSD-steels, optimized high strength and high ductility austenitic steel. Proceedings of International Conference on Super-High Strength Steels, pp. 1-12, Peschiera del Garda, Italy, October 17-20, 2010

Shin, S.Y.; Hong, S.; Kim, H.S.; Lee, S. \& Kim, N.J. (2010). Tensile properties and cup formability of high Mn and Al-added TWIP steels. Proceedings of International Conference on Super-High Strength Steels, pp. 1-9, Peschiera del Garda, Italy, October 17-20, 2010

Sojka, J.; Mazancova, E.; Schindler, I.; Kander, L.; Kozelsky, P.; Vanova, P. \& Wenglorzova, A. (2010). Resistance against hydrogen embrittlement of advanced materials for automotive industry. Proceedings of International Conference METAL, pp. 1-6, Roznov pod Radhostem, Czech Republic, May 18-20, 2010

Vercammen, S.; De Cooman, B.C.; Akdut, N.; Blanpain, B. \& Wollants, P. (2002). Microstructural evolution and crystallographic texture formation of cold rolled austenitic Fe-30Mn-3Al-3Si TWIP-steel. Proceedings of International Conference on TRIP-aided High-Strength Ferrous Alloys, pp. 55-60, Ghent, Belgium, June 19-21, 2002

Xu, J.; Sun, X.; Yuan, X. \& Wei, B. (1994). Hydrogen permeation and diffusion in low-carbon steels and 16Mn steel. Journal of Materials Science Technology, Vol.10, (1994), pp. $92-$ 96

Yang, Q. \& Luo, J.L. (2000). Martensite transformation and surface cracking of hydrogen charged and outgassed type 304 stainless steel. Materials Science and Engineering A, Vol.288, (2000), pp. 75-83

Zhang, Y.S. \& Zhu, X.M. (1999). Electrochemical polarization and passive film analysis of austenitic Fe-Mn-Al steels in aqueous solutions. Corrosion Science, Vol.41, (1999), pp. 1817-1833 


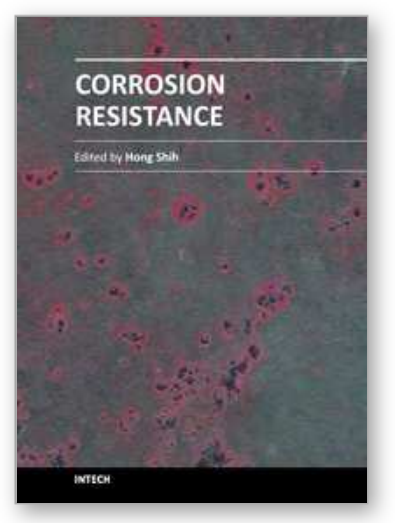

\author{
Corrosion Resistance \\ Edited by Dr Shih
}

ISBN 978-953-51-0467-4

Hard cover, 472 pages

Publisher InTech

Published online 30, March, 2012

Published in print edition March, 2012

The book has covered the state-of-the-art technologies, development, and research progress of corrosion studies in a wide range of research and application fields. The authors have contributed their chapters on corrosion characterization and corrosion resistance. The applications of corrosion resistance materials will also bring great values to reader's work at different fields. In addition to traditional corrosion study, the book also contains chapters dealing with energy, fuel cell, daily life materials, corrosion study in green materials, and in semiconductor industry.

\title{
How to reference
}

In order to correctly reference this scholarly work, feel free to copy and paste the following:

Adam Grajcar (2012). Corrosion Resistance of High-Mn Austenitic Steels for the Automotive Industry, Corrosion Resistance, Dr Shih (Ed.), ISBN: 978-953-51-0467-4, InTech, Available from:

http://www.intechopen.com/books/corrosion-resistance/corrosion-resistance-of-high-mn-austenitic-steels-forthe-automotive-industry

\section{INTECH}

open science | open minds

\section{InTech Europe}

University Campus STeP Ri

Slavka Krautzeka 83/A

51000 Rijeka, Croatia

Phone: +385 (51) 770447

Fax: +385 (51) 686166

www.intechopen.com

\section{InTech China}

Unit 405, Office Block, Hotel Equatorial Shanghai

No.65, Yan An Road (West), Shanghai, 200040, China

中国上海市延安西路65号上海国际贵都大饭店办公楼 405 单元

Phone: +86-21-62489820

Fax: +86-21-62489821 
(C) 2012 The Author(s). Licensee IntechOpen. This is an open access article distributed under the terms of the Creative Commons Attribution 3.0 License, which permits unrestricted use, distribution, and reproduction in any medium, provided the original work is properly cited. 